\title{
Kemampuan Penalaran Matematis pada Peserta Didik Via Mind Mapping
}

\section{Mathematical Reasoning Ability in Students Via Mind Mapping}

Siti Munawaroh ${ }^{1}$, Surahmat ${ }^{1}$, Abdul Halim Fathani ${ }^{*}$

${ }^{1}$ Program Studi Pendidikan Matematika, FKIP, Universitas Islam Malang

*Email Korespondensi: fathani@unisma.ac.id

\begin{tabular}{lll}
\hline \hline \multicolumn{2}{l}{ Info Artikel } & \\
\hline Diterima & $:$ & $27 \mathrm{Jan} 21$ \\
Direvisi & $:$ & $14 \mathrm{Feb} 21$ \\
Diterbitkan & $:$ & $28 \mathrm{Feb} 21$ \\
& & \\
& & \\
\end{tabular}

Kata Kunci:

Penalaran Matematis, Mind Mapping

Cara merujuk artikel ini:

Munawaroh, S., Surahmat, S., \& Fathani, A. H. (2021). Kemampuan Penalaran Matematis via Mind Mapping. Vygotsky: Jurnal Pendidikan Matematika dan Matematika, 3 (1), 63-76. Diunduh dari https://jurnalpendidikan. unisla.ac.id/index.php/ $\mathrm{VoJ} /$ article/view/344

\begin{abstract}
Students' mathematical reasoning abilities can be developed and assessed through mind mapping. This has become one of the media that can express ideas freely and creatively. This type of research is a qualitative descriptive study that aims to describe mathematical reasoning abilities through mind mapping media on numbers. The subjects of this study were selected using purposive sampling technique, namely there were 5 groups of students of class VII-G SMP Shalahuddin Malang who were able to represent the characteristics of the population that met the criteria. Data collection techniques, namely in the form of observation and interviews. The results of this study indicate that the reasoning process which represents the level of mathematical reasoning ability has different characters in showing that it fulfills each indicator of mathematical reasoning ability.
\end{abstract}

\begin{tabular}{l}
\hline Abstrak \\
Kemampuan penalaran matematis siswa dapat \\
dikembangkan dan dinilai melalui mind mapping. \\
Hal ini menjadi salah satu media yang dapat \\
mencurahkan gagasan-gagasan dengan bebas dan \\
kreatif. Jenis dalam penelitian ini adalah penelitian \\
deskriptif kualitatif yang bertujuan untuk \\
mendeskripsikan kemampuan penalaran matematis \\
melalui media mind mapping pada materi \\
bilangan. Subyek penelitian ini dipilih \\
menggunakan teknik purposive sampling, yakni \\
terdapat 5 kelompok peserta didik kelas VII-G SMP \\
Shalahuddin Malang yang mampu mewakili \\
karakteristik populasi yang memenuhi kriteria. \\
Teknik pengumpulan data, yaitu berupa observasi \\
dan wawancara. Hasil dari penelitian ini \\
menunjukkan bahwa proses bernalar yang \\
mewakili tingkat kemampuan penalaran matematis \\
memiliki karakter yang berbeda-beda dalam \\
memperlihatkan memenuhi setiap indikator \\
kemampuan penalaran matematis.
\end{tabular}

Copyright (C) 2021 Vygotsky: Jurnal Pendidikan Matematika dan Matematika. All right reserved 


\section{PENDAHULUAN}

Matematika merupakan ilmu dasar yang harus dipelajari bagi siapa pun. Matematika memiliki peran penting dalam pengembangan sains dan teknologi, serta pengembangan pola pikir manusia. Hal tersebut sejalan yang dengan ditegaskan National Council of Teachers of Mathematics (NCTM), menetapkan lima standar untuk keterampilan matematika yang harus dimiliki siswa, yaitu kemampuan untuk menyelesaikan masalah (problem solving), keterampilan komunikasi (communication), konektivitas (connection), keterampilan penalaran (reasoning), dan representasi (representation) (Yilmaz, Zuhal., 2014).

Kemampuan penalaran atau pemikiran matematis yang dibahas dalam penelitian ini didefinisikan sebagai proses berpikir dinamika yang memungkinkan untuk meningkatkan kompleksitas gagasan yang dapat ditangani dan memperluas pemahaman (Zaman, Amir., Juman., Alamgir., Ali, Arshad., 2011)). Berikut adalah indikator kemampuan penalaran matematis siswa.

Tabel 1. Indikator Kemampuan Penalaran Matematis

\begin{tabular}{|c|c|c|}
\hline No & $\begin{array}{l}\text { Indikator Kemampuan } \\
\text { Penalaran }\end{array}$ & Kriteria \\
\hline 1 & Mengajukan dugaan; & $\begin{array}{l}\text { Mengajukan dugaan yang kemudian } \\
\text { dibuktikan dengan menampilkan } \\
\text { beragam konsep yang dikuasai siswa } \\
\text { yang ada hubungannya dengan } \\
\text { permasalahan yang diberikan }\end{array}$ \\
\hline 2 & $\begin{array}{l}\text { Melakukan manipulasi } \\
\text { matematika; }\end{array}$ & $\begin{array}{l}\text { Melakukan manipulasi matematika } \\
\text { untuk mengubah soal cerita menjadi } \\
\text { kalimat matematika. }\end{array}$ \\
\hline 3 & $\begin{array}{l}\text { Menarik kesimpulan, menyusun } \\
\text { bukti, memberikan alasan atau } \\
\text { bukti terhadap kebenaran } \\
\text { solusinya; }\end{array}$ & $\begin{array}{l}\text { Menarik kesimpulan dari soal dan } \\
\text { pernyataan cerita yang masih perlu } \\
\text { diselesaikan/dijabarkan. }\end{array}$ \\
\hline 4 & $\begin{array}{l}\text { Menarik kesimpulan dari } \\
\text { pernyataan; }\end{array}$ & $\begin{array}{l}\text { Mengungkapkan alasan kebenaran } \\
\text { suatu pernyataan. }\end{array}$ \\
\hline 5 & $\begin{array}{l}\text { Memeriksa kesahihan suatu } \\
\text { argumen; }\end{array}$ & $\begin{array}{l}\text { Menjawab soal, dimulai dengan } \\
\text { menyebutkan jawaban atas masalah } \\
\text { atau pernyataan yang sengaja } \\
\text { dilakukan salah. }\end{array}$ \\
\hline
\end{tabular}

Adapun tugas pokok dari pendidikan yaitu memperbaiki aktivitas pembelajaran matematika di sekolah. Faktanya, tidak sedikit kegiatan pembelajaran matematika di sekolah yang masih menerapkan pembelajaran konvensional yang cenderung prosedural, monoton, dan guru lebih bersifat dominan dalam kegiatan pembelajaran di kelas. Berdasarkan hasil observasi lapangan yang dilakukan peneliti dalam kegiatan pembelajaran, yaitu: pertama, guru menjelaskan materi yang dipelajari; kedua, guru memberikan contoh; ketiga, memberikan tugas; keempat, mengerjakan latihan soal; kelima, mengkoreksi jawaban siswa 
dengan sekilas, dan yang terakhir melakukan pembahasan pemecahan masalah yang kemudian dicontoh dan ditulis oleh siswa.

Pehkonen (Fun, Sok Chin., \& Norhayati, 2010) menyatakan bahwa pemetaan pikiran (mind mapping) bermanfaat bagi siswa yang mengambil pendidikan matematika. Berpikir matematis melibatkan 2 (dua) sisi otak, yakni sisi kiri termasuk deduksi analitik dan aritmatika, sedangkan sisi kanan mencakup tugas spasial seperti geometri. Dalam pembelajaran matematika, penekanan konstan pada aturan dan algoritma biasanya pada kemampuan berurutan dan spasial. Dengan menggunakan peta pikiran, dua bagian otak dapat bekerja secara bersamaan, saling melengkapi, dan saling menguatkan antara bagian otak satu dengan bagian otak lainnya, dan memiliki lebih sedikit konflik otak satu dengan lainnya.

Media pembelajaran mind mapping merupakan media pembelajaran menggunakan sebuah peta konsep yang dilakukan dengan mencatat materi belajar yang dituangkan dalam bentuk diagram yang dapat membantu siswa untuk empelajari dan mengingat suatu konsep. Diagram yang digunakan dalam peta konsep memuat kode, simbol, gambar, dan warna-warni yang saling berhubung-hubungan. Mind Mapping merupakan salah satu cara untuk memetakan pikiran, ide, atau gagasan secara kreatif dan efektif (Buzan, 2009). Pembelajaran dengan mind mapping dapat menjadikan siswa merasa senang dan tidak bosan dalam mengikuti proses pembelajaran sehingga dapat meningkatkan hasil belajar (Imaduddin, 2019). Pemetaan pikiran, juga dikenal sebagai peta otak atau pikiran, adalah cara berpikir inovatif yang diperkenalkan oleh Tony Buzan yang terkenal Ahli Psikolog Inggris pada 1960-an. Peta pikiran menggabungkan konsep di seluruh otak yang mencakup logika, urutan, prosedur, kata-kata dan angka dari otak kiri, dan gambar, imajinasi, warna, ruang, dan keseluruhan otak kanan (Liu, Yizhen., Tong, Yingxin., \& Yuqi, 2018).

Untuk membuat mind mapping, bahan yang diperlukan adalah sebagai berikut: 1) Kertas, minimal berukuran A4; 2) Pensil warna atau spidol; 3) Imajinasi; dan 4) Otak kita sendiri. Menurut Alamsyah (Wira Negara, 2015) menjelaskan setiap peta pikiran (mind map) mempunyai elemen-elemen sebagai berikut: 1) Pusat peta pikiran (central topic), yang merupakan ide atau gagasan utama. 2) Cabang utama (basic ordering ideas (BOI)), cabang tingkat pertama yang langsung memancar dari pusat peta pikiran. 3) Cabang, merupakan pancaran dari cabang utama, dapat dituliskan ke segala arah. 4) Kata, menggunakan kata kunci saja. 5) Gambar, dapat menggunakan gambar-gambar yang disukainya. 6) Warna, gunakan warna-warni yang menarik dalam peta pikiran. (Buzan, 2009).

Menurut Buzan (2009) terdapat tujuh langkah dalam membuat mind mapping, yaitu:

1. Mulailah dari bagian tengah yang menjadi pokok utama pembahasan.

2. Gunakan gambar atau foto untuk ide sentral.

3. Gunakan warna-warna yang menariknya dengan gambar. 
4. Hubungkan cabang-cabang utama ke gambar pusat dan hubungkan cabang-cabang tingkat dua dan tiga ke tingkat satu dan dua, dan seterusnya.

5. Buatlah garis hubung yang melengkung.

6. Gunakan satu kata kunci untuk setiap garis.

7. Gunakan gambar pada beberapa cabang atau anak cabang, karena gambar bermakna.

Dari tujuh langkah-langkah dalam membuat mind mapping di atas, dapat disimpulkan bahwa media ini dapat mempersingkat catatan pelajaran, dan catatan tersebut dapat bervariasi karena banyak warna sesuai dan disukai oleh siswa.

Pemetaan pikiran memungkinkan siswa untuk membayangkan dan mengeksplorasi hubungan antara konsep. Peta pikiran terdiri jaringan konsep terhubung dan terkait. Namun, dalam pemetaan pikiran, ide dapat dihubungkan ke yang lain. Bentuk-bebas, pemikiran spontan diperlukan saat membuat peta pikiran, dan tujuan pemetaan pikiran adalah untuk menemukan asosiasi kreatif antara ide-ide siswa. (Davies, 2011).

Kegunaan utama dari pemetaan pikiran adalah untuk menciptakan asosiasi ide. Keuntungan dari pemetaan pikiran termasuk "bentuk bebas" dan strukturnya yang tidak dibatasi.(W. Martin, 2011). Beberapa penelitian terdahulu yang relevan dan menguatkan perlunya meningkatkan kemampuan penalaran matematis dengan mind mapping, antara lain: (Mahmudah, 2018) menunjukkan bahwa penggunaan model pembelajaran mind mapping dapat meningkatkan penalaran dan kreativitas peserta didik. (Marsitin, 2018) menyimpulkan pembelajaran discovery berbasis mind map dapat meningkatkan kemampuan penalaran matematik dan meningkatkan keberhasilan akademik mahasiswa, sehingga pembelajaran lebih berkualitas. (Yuliantin, 2018) menunjukkan bahwa: (1) Pembelajaran matematika dengan menggunakan Pendekatan pembelajaran Mind Mapping dapat meningkatkan kemampuan penalaran matematis siswa; (2) Pembelajaran matematika dengan menggunakan Pendekatan pembelajaran Mind Mapping dapat meningkatkan motivasi siswa; (3) Terdapat perbedaan peningkatan kemampuan penalaran antara siswa yang menggunakan pembelajaran dengan Pendekatan pembelajaran Mind Mapping dan siswa yang menggunakan metode Konvensional.

\section{METODE PENELITIAN}

Jenis penelitian yang digunakan dalam penelitian ini yaitu penelitian deskriptif kualitatif. Penelitian ini menggunakan data kualitatif dan mendeskripsikan fenomena factual yang menghasilkan gambaran yang jelas dan terperinci mengenai tingkat kemampuan penalaran matematis peserta didik. Penelitian ini dilakukan di SMP Salahuddin Malang. Berdasarkan hasil observasi dan wawancara dengan guru, sesuai dengan 
tujuan penelitian, pemilihan subjek penelitian diambil dari peserta didik kelas VII-G SMP Shalahuddin Malang sebanyak 30 peserta didik. Peneliti mengambil kelas VII-G sebagai objek penelitian karena kelas tersebut mampu mewakili karakteristik populasi yang ditetapkan. Adapun yang terpilih sebagai subjek merupakan peserta didik yang memiliki kemampuan penalaran matematis dan pembuatan mind mapping dalam lima kelompok berikut, yaitu kemampuan bernalar sangat baik, baik, cukup baik dan kurang baik.

Adapun grafik ketuntasan belajar siswa dalam kemampuan penalaran dan pembuatan mind mapping sebagai berikut.

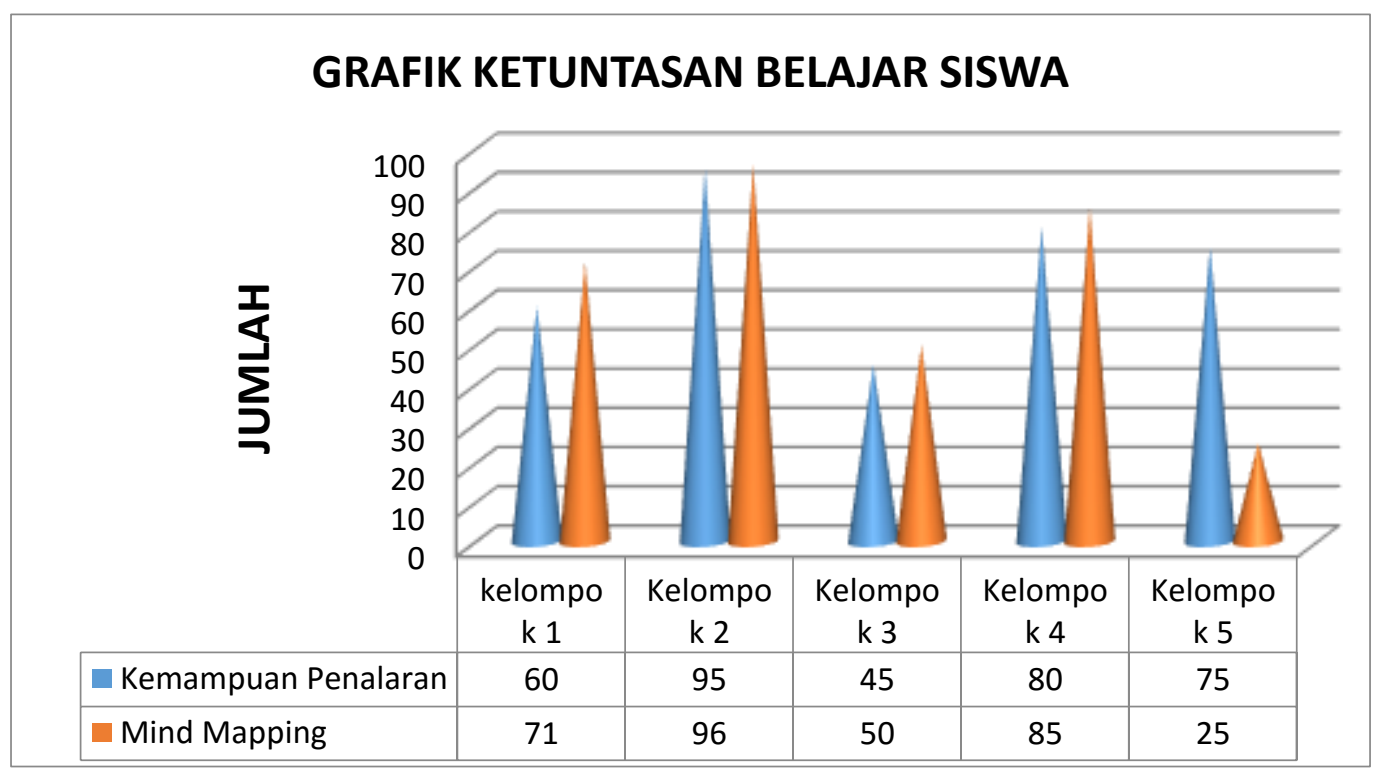

Gambar 1. Grafik Ketuntasan Belajar Siswa

Adapun ketentuan taran keberhasilan siswa dalam kemampuan penalaran dan pembuatan mind mapping dipaparkan dalam Tabel 1 berikut.

Tabel 1. Ketentuan Taraf Keberhasilan

\begin{tabular}{cc}
\hline Persentase Skor Rata-rata (SR) & Taraf Keberhasilan \\
\hline $75 \% \leq \mathrm{SR} \leq 100 \%$ & Sangat berhasil \\
\hline $50 \% \leq \mathrm{SR}<75 \%$ & Berhasil \\
\hline $25 \% \leq \mathrm{SR}<50 \%$ & Cukup berhasil \\
\hline $0 \%<\mathrm{SR}<25 \%$ & Kurang berhasil \\
\hline
\end{tabular}

Dengan berdasarkan hasil tes kemampuan penalaran matematis dan hasil pembuatan mind mapping kelima kelompok subjek tersebut yaitu diantaranya: 1). Kelompok 2 termasuk dalam kategori sangat baik; 2). Kelompok 1 termasuk dalam kategori baik; 3). Kelompok 4 termasuk dalam kategori baik; 4). Kelompok 3 termasuk dalam kategori kurang baik; 5). Kelompok 5 yang mewakili kategori kurang baik.

Penyajian data yang dilakukan oleh peneliti yaitu mengklasifikasikan 
dan mendeskripsikan berdasarkan lima indikator kemampuan penalaran matematis peserta didik dikategorikan pada tingkat kemampuan penalaran yang terdiri dari empat tingkat kategori, yaitu sangat baik, baik, cukup baik dan kurang baik. Terakhir menarik kesimpulan atau verfikasi untuk mendeskripsikan tingkat kemampuan penalaran pada setiap kelompok berdasarkan penyajian data.

\section{HASIL DAN PEMBAHASAN}

Dalam kemampuan penalaran terdapat 5 (lima) indikator yang dikelompokkan ke dalam 4 (empat) tingkat kemampuan bernalar yaitu: (1) Kelompok 2 termasuk kategori sangat baik; (2) Kelompok 1 dan 4 termasuk kategori baik; (3) Kelompok 3 termasuk kategori cukup baik; dan (4) Kelompok 5 termasuk kategori kurang baik. Berdasarkan hasil pembutan media mind mapping siswa menunjukkan bahwa terdapat perbedaan deskripsi dari masing-masing tingkat kemampuan penalaran matematis pada materi bilangan. Lima kelompok siswa ini terdistribusi dalam empat kategori tingkat kemampuan bernalar. Hal ini sependapat dengan (Yuliantin, 2018) yang menyatakan bahwa terdapat perbedaan peningkatan kemampuan penalaran antara siswa yang menggunakan pembelajaran dengan Pendekatan pembelajaran Mind Mapping dan siswa yang menggunakan metode Konvensional. Berikut hasil dari setiap tingkatan kemampuan penalaran matematis siswa.

\section{Subjek Kelompok 2 memiliki Tingkat Kemampuan Penalaran Matematis dan (Sangat Baik)}

Subjek kelompok 2 termasuk dalam golongan tingkat kemampuan penalaran matematis (sangat baik) hal ini dibuktikan dari hasil tes subjek kelompok 2 telah memenuhi dari 5 indikator kemampuan penalaran matematis yaitu: mengajukan dugaan; melakukan manipulasi matematika; menarik kesimpulan, menyusun bukti, memberikan alasan atau bukti terhadap kebenaran solusinya; menarik kesimpulan dari pernyataan; dan memeriksa kesahihan suatu argumen. Seperti yang terlihat pada Gambar 2, subjek kelompok 2 mampu menyelesaikan permasalahan dengan lancar dan runtut dan subjek juga dapat menyelesaikannnya berdasarkan peta pemikiran (mind mapping) dengan sangat baik. Hal tersebut menunjukkan bahwa 5 indikator mampu diperlihatkan oleh kelompok 2, dimana subjek mampu menyelesaikan soal bilangan dengan lancar dan benar. Subjek kelompok 2 ini mendukung hasil penelitian yang dilakukan Mahmudah (2020), yakni dengan penggunaan model pembelajaran mind mapping dapat meningkatkan penalaran matematik siswa. 


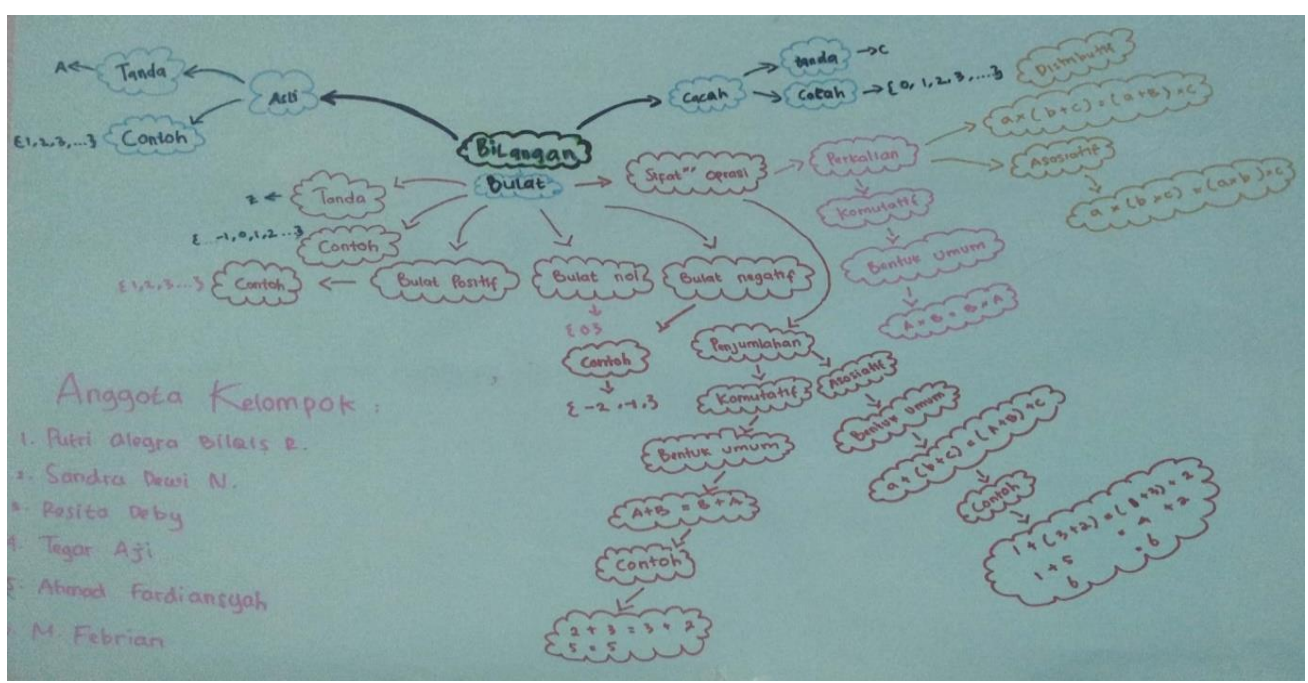

Gambar 2. Kelompok 2 (Kategori Sangat Baik)

Penggunaan utama dari pemetaan pikiran adalah untuk menciptakan sebuah ide atau gagasan. Berdasarkan dari gambar di atas dapat diketahui bahwa kelompok 2 tersebut dapat menyelesaikan tugas mind mapping dengan sangat baik. Jadi kesimpulan pada kelompok 2 sudah memenuhi 7 kriteria yaitu memulai dari bagian tengah yang dijadikan pokok bahasan utama, memberikan ide sentral, menggunakan warna-warna yang menarik, dapat menghubung-hubungkan cabang, membuat garis hubung yang melengkung, menggunakan satu kata kunci untuk setiap garis, dan menggunakan masing-masing kode cabang agar lebih mudah diingat dan untuk dimengerti dalam pembuatan mind mapping dengan runtut dan benar. Artinya bahwa subjek kelompok 2 pada hasil pembuatan mind mapping siswa dalam kriteria sangat baik dan subjek juga menunjukkan bahwa 5 indikator kemampuan penalaran matematis mampu diperlihatkan, dimana dapat menyelesaikan soal bilangan dengan benar.

\section{Subjek Kelompok 1 memiliki Tingkat Kemampuan Penalaran Matematis (Baik)}

Subjek kelompok 1 termasuk dalam golongan tingkat kemampuan penalaran matematis (baik) hal ini dibuktikan dari hasil tes subjek telah memenuhi 3 dari indikator kemampuan penalaran matematis yaitu, mengajukan dugaan; menyusun bukti, menarik kesimpulan dari pernyataan; dan memeriksa kesahihan suatu argumen. seperti yang terlihat pada Gambar 4, subjek kelompok 1 cukup mampu menyelesaikan permasalahan dengan lancar dan runtut dan subjek juga dapat menyelesaiannnya berdasarkan peta pemikiran dengan cukup baik. Hal tersebut menunjukkan bahwa 3 indikator mampu diperlihatkan oleh kelompok 1, dimana subjek cukup mampu menyelesaikan soal bilangan dengan cukup lancar dan benar. 


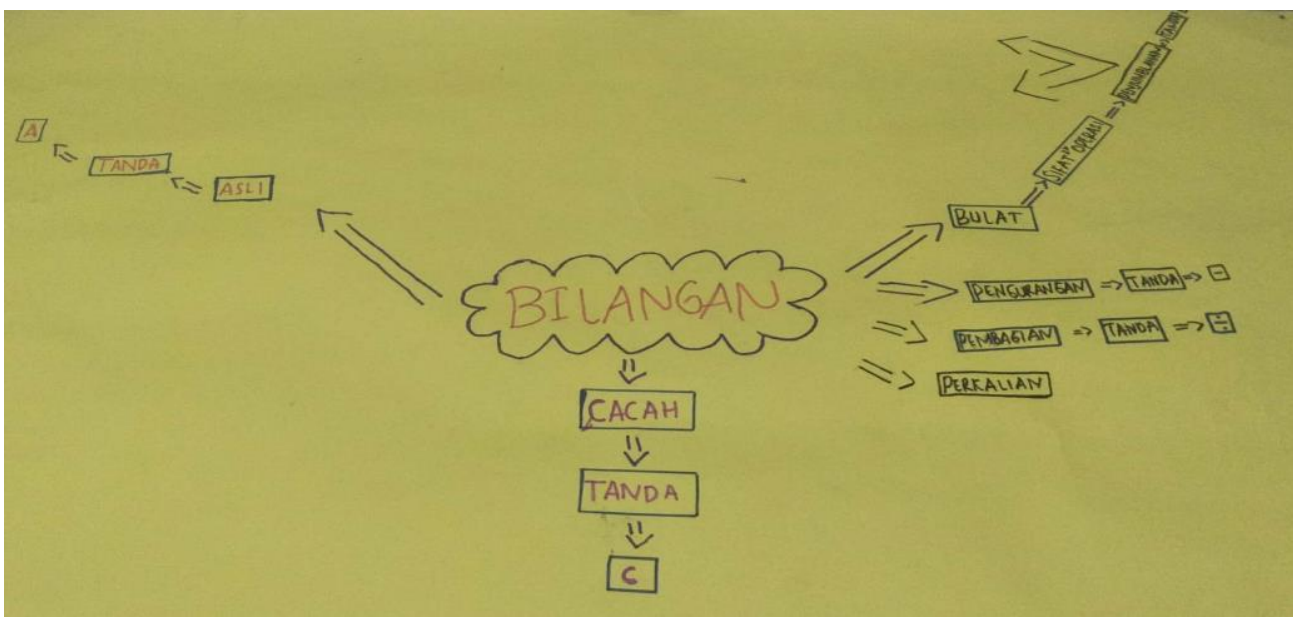

Gambar 3. Kelompok 1 (Kategori Baik)

Penggunaan utama dari pemetaan pikiran adalah untuk menciptakan sebuah ide atau gagasan. Dalam Peta Pikiran, hierarki dan asosiasi mengalir keluar dari citra sentral dengan cara yang mengalir bebas, namun terorganisir dan koheren. Topik atau kategori utama yang terkait dengan topik utama ditangkap oleh cabang yang mengalir dari gambar pusat (Arulselvi, 2017). Berdasarkan dari gambar diatas dapat diketahui bahwa kelompok 1 tersebut dapat menyelesaikan tugas mind mapping dengan cukup baik. Jadi kesimpulan pada kelompok 1 cukup memenuhi beberapa kriteria pembuatan mind mapping yaitu memulai dari bagian tengah yang dijadikan pokok bahasan utama, memberikan ide sentral, cukup menggunakan warna-warna yang menarik, menghubunghubungkan cabang dengan cukup baik, menggunakan satu kata kunci untuk setiap garis, dan cukup menggunakan masing-masing kode cabang agar lebih mudah diingat dan untuk dimengerti dalam pembuatan mind mapping dengan runtut dan benar. Artinya bahwa subjek kelompok 1 pada hasil pembuatan mind mapping siswa dalam kriteria cukup baik dan subjek juga menunjukkan bahwa 3 indikator kemampuan penalaran matematis mampu diperlihatkan, dimana cukup mampu dalam menyelesaikan soal bilangan dengan lancar dan benar.

\section{Subjek Kelompok 4 memiliki Tingkat Kemampuan Penalaran Matematis (Baik)}

Subjek kelompok 4 termasuk dalam golongan tingkat kemampuan penalaran matematis (baik) hal ini dibuktikan dari hasil tes subjek telah memenuhi 4 dari indikator kemampuan penalaran matematis yaitu, mengajukan dugaan; menyusun bukti, memberikan alasan atau bukti terhadap kebenaran solusinya; menarik kesimpulan dari pernyataan; dan memeriksa kesahihan suatu argumen. seperti yang terlihat pada Gambar 3, subjek kelompok 4 mampu menyelesaikan permasalahan dengan lancar dan runtut dan subjek juga dapat menyelesaiannnya berdasarkan peta pemikiran dengan baik. Hal tersebut menunjukkan bahwa 4 indikator mampu diperlihatkan oleh kelompok 4, dimana subjek mampu menyelesaikan soal bilangan dengan lancar dan benar. 


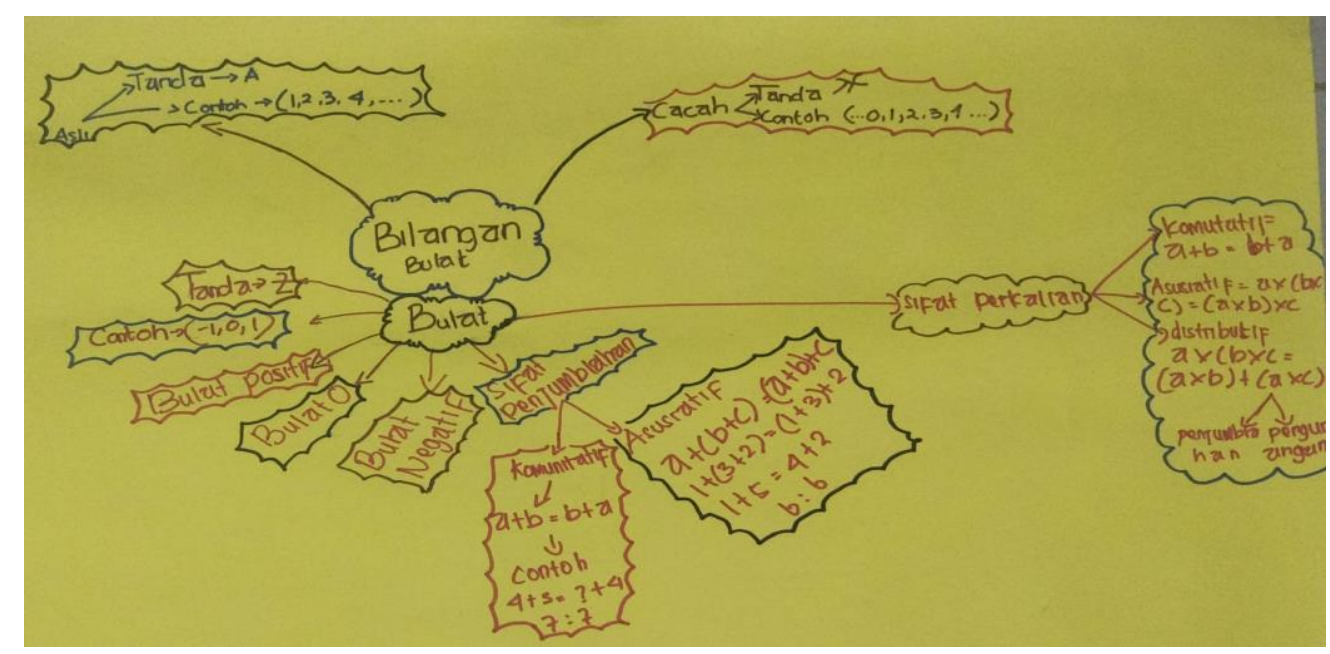

Gambar 4. Kelompok 4 (Kategori Baik)

Penggunaan utama dari pemetaan pikiran adalah untuk menciptakan sebuah ide atau gagasan. Berdasarkan dari gambar diatas dapat diketahui bahwa kelompok 4 tersebut dapat menyelesaikan tugas mind mapping dengan baik. Jadi kesimpulan pada kelompok 4 sudah memenuhi 7 kriteria pembuatan mind mapping yaitu memulai dari bagian tengah yang dijadikan pokok bahasan utama, memberikan ide sentral, menggunakan warna-warna yang menarik, dapat menghubung-hubungkan cabang, membuat garis hubung yang melengkung, menggunakan satu kata kunci untuk setiap garis, dan menggunakan masing-masing kode cabang agar lebih mudah diingat dan untuk dimengerti dalam pembuatan mind mapping dengan runtut dan benar. Artinya bahwa subjek kelompok 4 pada hasil pembuatan mind mapping siswa dalam kriteria baik dan subjek juga menunjukkan bahwa 4 indikator kemampuan penalaran matematis mampu diperlihatkan, dimana dapat menyelesaikan soal bilangan dengan lancar dan benar.

\section{Subjek Kelompok 3 memiliki Tingkat Kemampuan Penalaran Matematis (Cukup Baik)}

Subjek kelompok 3 termasuk dalam golongan tingkat kemampuan penalaran matematis (Cukup baik). Hal ini dibuktikan dari hasil tes subjek hanya memenuhi 2 dari indikator kemampuan penalaran matematis yaitu, menarik kesimpulan dari pernyataan; dan memeriksa kesahihan suatu argumen. seperti yang terlihat pada Gambar 5, subjek kelompok 3 kurang mampu menyelesaikan permasalahan dengan lancar dan runtut dan subjek juga dapat menyelesaiannnya berdasarkan peta pemikiran dengan kurang baik. Hal tersebut menunjukkan bahwa 2 indikator mampu diperlihatkan oleh kelompok 3, dimana subjek kurang mampu menyelesaikan soal bilangan dengan lancar dan benar. 


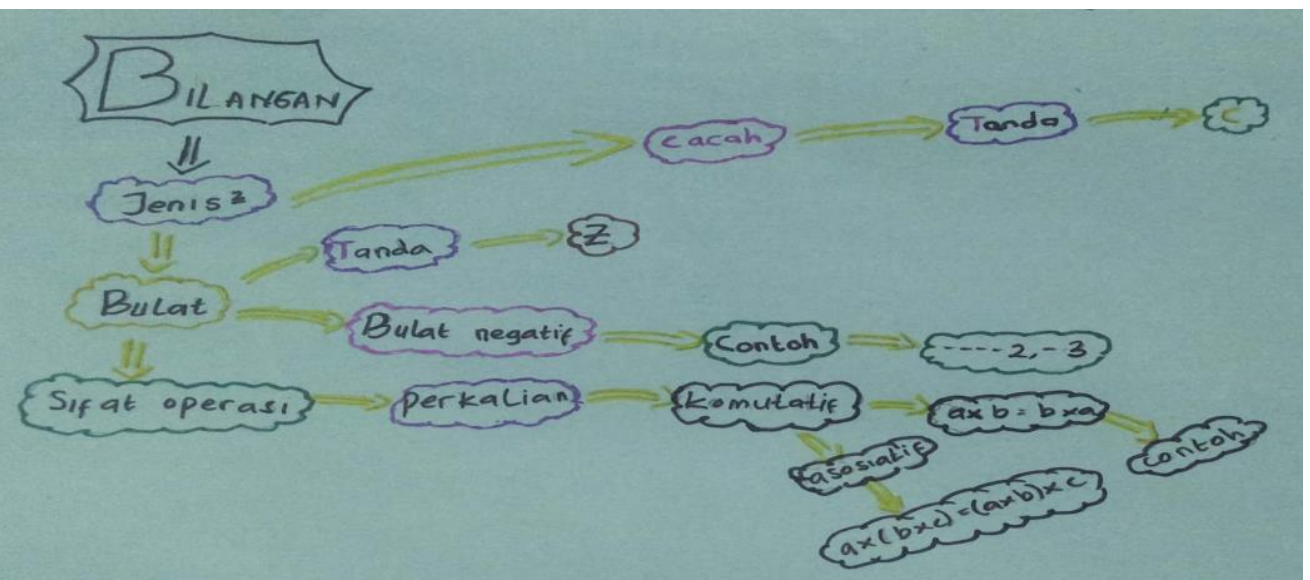

Gambar 5. Kelompok 3 (Kategori Cukup Baik)

Penggunaan utama dari pemetaan pikiran adalah untuk menciptakan sebuah ide atau gagasan. Berdasarkan dari gambar diatas dapat diketahui bahwa kelompok 3 tersebut dapat menyelesaikan tugas mind mapping dengan cukup baik. Jadi, kesimpulan pada kelompok 3 hanya memenuhi beberapa kriteria pembuatan mind mapping yaitu memulai dari bagian tengah yang dijadikan pokok bahasan utama, memberikan ide sentral, kurang menggunakan warna-warna yang menarik, kurang benar dalam menghubung-hubungkan cabang, dan kurang menggunakan masing-masing kode cabang agar lebih mudah diingat dan untuk dimengerti dalam pembuatan mind mapping dengan runtut dan benar. Artinya bahwa subjek kelompok 1 pada hasil pembuatan mind mapping siswa dalam kriteria kurang baik dan subjek juga menunjukkan bahwa 2 indikator kemampuan penalaran matematis mampu diperlihatkan, dimana siswa kurang mampu dalam menyelesaikan soal bilangan dengan lancar dan benar.

\section{Subjek Kelompok 5 Memiliki Tingkat Kemampuan Penalaran Matematis (Kurang Baik)}

Subjek kelompok 5 termasuk dalam golongan tingkat kemampuan penalaran matematis (Kurang Baik). Hal ini dibuktikan dari hasil tes subjek memenuhi 4 dari indikator kemampuan penalaran matematis yaitu, mengajukan dugaan; menarik kesimpulan, menyusun bukti, memberikan alasan atau bukti terhadap kebenaran solusinya; menarik kesimpulan dari pernyataan; dan memeriksa kesahihan suatu argumen. Seperti yang terlihat pada Gambar 6, subjek kelompok 5 cukup mampu menyelesaikan tes dengan lancar dan benar namun dalam menyelesaiakan peta pemikiran (mind mapping) siswa dikatakan dalam kriteria tidak baik dikarenakan tidak dapat memenuhi 7 dari kriteria mind mapping. Hal tersebut menunjukkan bahwa 4 indikator mampu diperlihatkan oleh kelompok 5, dimana subjek dapat menyelesaikan soal bilangan dengan lancar dan benar. 


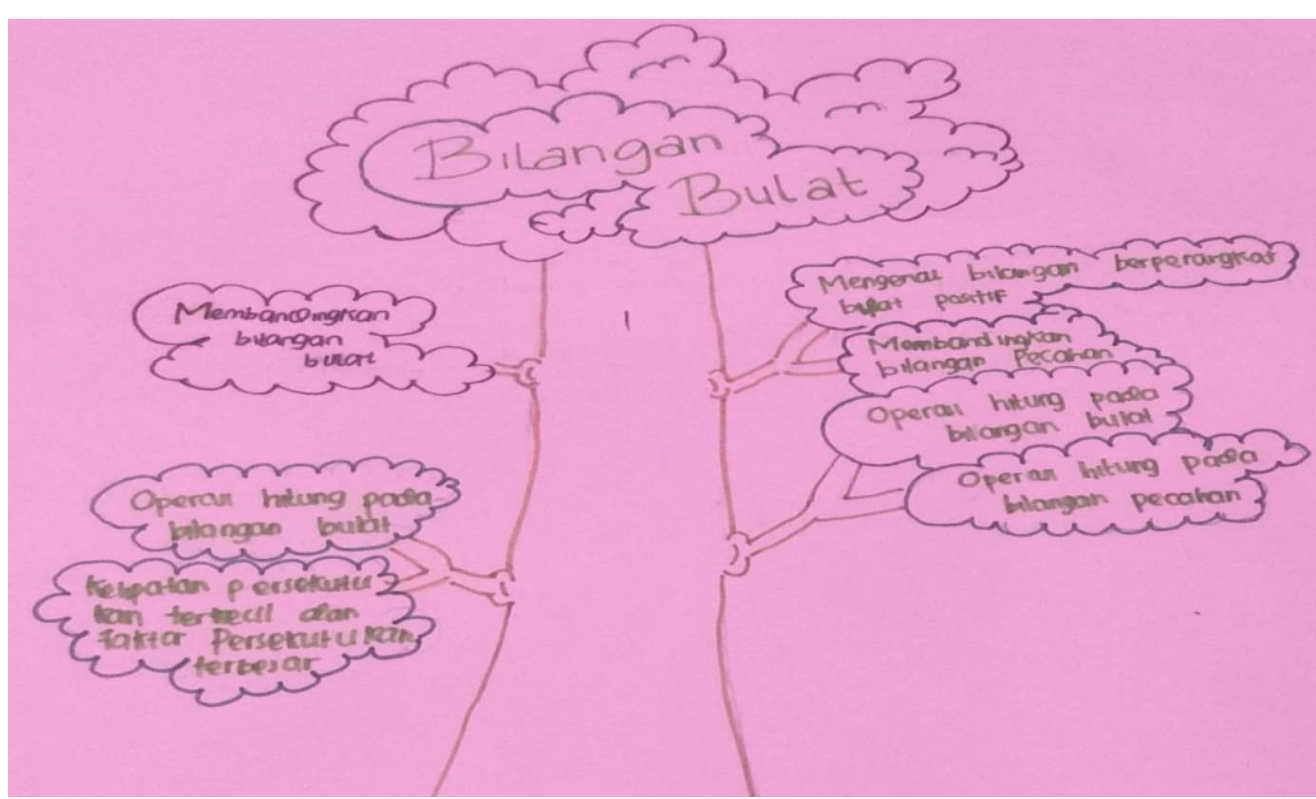

Gambar 6. Kelompok 5 (Kurang Baik)

Penggunaan utama dari pemetaan pikiran adalah untuk menciptakan sebuah ide atau gagasan. Berdasarkan dari gambar diatas dapat diketahui bahwa kelompok 5 tersebut dapat menyelesaikan tugas mind mapping dengan tidak baik karena konsep yang mereka gunakan adalah konsep dari argumen mapping bukan dari konsep mind mapping. Jadi kesimpulan pada kelompok 5 tidak memenuhi 7 kriteria pembuatan mind mapping yaitu memulai dari bagian tengah yang dijadikan pokok bahasan utama, memberikan ide sentral, menggunakan warna-warna yang menarik, dapat menghubung-hubungkan cabang, membuat garis hubung yang melengkung, menggunakan satu kata kunci untuk setiap garis, dan menggunakan masing-masing kode cabang agar lebih mudah diingat dan untuk dimengerti dalam pembuatan mind mapping dengan runtut dan benar. Artinya bahwa subjek kelompok 5 pada hasil pembuatan mind mapping siswa dalam kriteria tidak baik namun argumen maping yang telah dibuat oleh kelompok 5 dalam pemetaan memungkinkan penyajian materi baru untuk membangun pengetahuan yang ada. Dan subjek juga menunjukkan bahwa 4 indikator kemampuan penalaran matematis mampu diperlihatkan, dimana siswa mampu dalam menyelesaikan soal bilangan dengan lancar dan benar.

Berdasarkan antara hasil tes dengan hasil pembuatan media mind mapping pada masig-masing kelompok bahwa proses bernalar siswa yang mewakili tingkat kemampuan penalaran matematis yang sangat baik dapat disimpulkan bahwa dalam pembuatan media mind mapping dipastikan juga bernilai sangat baik.

Pemetaan Pikiran dikembangkan sebagai teknik mencatat dan menghafal pribadi. Ini sangat efektif sebagai teknik belajar dan belajar, sebagai tekstur yang kaya dari Pikiran yang dipersonalisasi. (Duffill, 2013). Pemetaan pikiran dapat menjadi alat terbaik untuk membuat dan merevisi konsep atau materi pelajaran yang dipelajari (Jogan, 2020). Sejalan dengan hasil penelitian (Marsitin, 2018) bahwa pembelajaran 
berbasis mind mapping dapat meningkatkan kemampuan penalaran matematik dan meningkatkan keberhasilan akademik mahasiswa, sehingga pembelajaran lebih berkualitas. Namun hal tersebut tidak berlaku untuk siswa yang dalam keadaan miskonsepsi dalam pembuatan media mind mapping sejak awal pembelajaran. Pada masing-masing kelompok memiliki karakter yang berbeda-beda dalam memperlihatkan setiap indikator kemampuan penalaran matematis.

\section{SIMPULAN DAN SARAN}

Hasil dari penelitian ini dapat disimpulkan bahwa proses bernalar yang mewakili tingkat kemampuan penalaran matematis memiliki karakter yang berbeda-beda dalam memperlihatkan memenuhi setiap indikator kemampuan penalaran matematis. Untuk kategori sangat baik, yakni subjek kelompok 2 menunjukkan bahwa dari 5 indikator kemampuan penalaran matematis mampu diperlihatkan, dimana dapat menyelesaikan soal bilangan dengan benar. Untuk kategori baik terdapat 2 kelompok subjek, yaitu subjek kelompok 1 menunjukkan bahwa 3 indikator kemampuan penalaran matematis mampu diperlihatkan, dimana cukup mampu dalam menyelesaikan soal bilangan dengan lancar dan benar. Sedangkan subjek kelompok 4 menunjukkan bahwa 4 indikator kemampuan penalaran matematis mampu diperlihatkan, dimana dapat menyelesaikan soal bilangan dengan lancar dan benar. Untuk kategori cukup baik, yaitu pada subjek kelompok 1 menunjukkan bahwa 2 indikator kemampuan penalaran matematis mampu diperlihatkan, dimana siswa kurang mampu dalam menyelesaikan soal bilangan dengan lancar dan benar. Adapun untuk kategori kurang baik, subjek kelompok 5 pada hasil pembuatan mind mapping siswa dalam kriteria tidak baik namun argumen maping yang telah dibuat oleh kelompok 5 dalam pemetaan memungkinkan penyajian materi baru untuk membangun pengetahuan yang ada. Dan subjek ini juga menunjukkan bahwa 4 indikator kemampuan penalaran matematis mampu diperlihatkan, dimana siswa mampu dalam menyelesaikan soal bilangan dengan lancar dan benar.

Adapun saran dalam penelitian ini antara lain: dapat dijadikan acuan bagi guru matematika hendaknya lebih mengembangkan pembelajaran yang dapat meningkatkan tingkat kemampuan kemampuan penalaran matematis peserta didik melalaui media mind mapping. Sedangkan untuk peneliti lainnya, dapat melakukan penelitian yang dapat berkontribusi dalam upaya meningkatkan kemampuan penalaran matematis peserta didik melalui media lain yang sesuai dengan karakteristik peserta didik.

\section{DAFTAR RUJUKAN}

Arulselvi, E. (2017) 'Mind Maps in Classroom Teaching and Learning', The Excellence in Education Journal, 6(2), pp. 50-65.

Buzan, T. (2009) Buku Pintar Mind Map. Jakarta: PT Gramedia Pustaka Utama. 
Davies, M. (2011) 'Concept Mapping, Mind Mapping And Argument Mapping: What Are The Differences And Do They Matter.', Jurnal High Educ, 62(1), pp. 279-301.

Duffill, N. (2013) 'Choosing and using Mind Maps and Concept Maps: A short conversion course for Mind Mappers', 1(2), pp. 1-7. Available at: https://www.olympic-limited.co.uk/wpcontent/uploads/2013/05/Choosing-and-using-Mind-Mapsand-Concept-Maps.pdf.

Fun, Sok Chin., \& Norhayati, M. (2010) 'Teacher-Centered Mind Mapping Vs Student-Centered Mind Mapping In The Teaching Of Accounting At Pre-U Level - An Action Research', Procedia Social and Behavioral Sciences, 7(C), pp. 240-246.

Imaduddin, M. C. \& U. H. N. U. (2019) ‘Efektivitas Metode Mind Mapping untuk Meningkatkan Prestasi Belajar Fisika Pada Siswa Kelas VIII', Jurnal Humanitas, IX(1), pp. 62-75.

Jogan, S. N. (2020) 'Mind Mapping: A Tool for Developing Creativity in Students', Studies in Indian Place Names (UGC Care Journal), 40(70), pp. 4007-4012.

Liu, Yizhen., Tong, Yingxin., \& Yuqi, Y. (2018) 'The Application of Mind Mapping into College Computer Programming Teaching', Procedia Computer Science, 129(1), pp. 66-70.

Mahmudah, F. H. (2018) 'Pembelajaran mind mapping untuk meningkatkan penalaran dan kreativitas peserta didik.', Indonesian Digital Journal of Mathematics and Education, 5(9), pp. 611-622.

Marsitin, R. (2018) 'Kemampuan Penalaran Matematik dalam Pembelajaran Discovery Berbasis Mind Map pada Fungsi Kompleks', Jurnal Tadris Matematika, 1(1), pp. 55-64.

W. Martin, D. (2011) 'Concept Mapping, Mind Mapping and Argument Mapping: What are the Differences and Do They Matter?', http://www.reasoninglab.com/, 62(3), pp. 279-301.

Yilmaz, Zuhal., \& Z. O. T. (2014) 'Connecting Mathematical Reasoning And Language Arts Skills: The Case Of Common Core State Standards.', Procedia - Social And Behavioral Sciences, 116(21), pp. 3716-3721. Available at: https://www.sciencedirect.com/science/article/pii/S187704281 4008465.

Yuliantin, E. (2018) Pendekatan Pembelajaran Mind Mapping untuk Meningkatkan Motivasi Belajar dan Penalaran Siswa dalam Pembelajaran Matematika pada Materi Segiempat dan Segitiga Siswa Kelas VII di SMPN 5 Sumedang. Universitas Pasundan Bandung.

Zaman, Amir., Juman., Alamgir., Ali, Arshad., \& M. A. H. (2011) 'Predictive Validity of Scores in Mathematics for Reasoning Ability in Mathematics for Grade 9 Students in Khyber Pakhtunkhwa Based on Curriculum of Mathematics.', Procedia Social and Behavioral Sciences, 12, pp. 588-594. 
